\title{
European Cinematic Diagnoses of Crises
}

\author{
Post-Crisis European Cinema. White Men in Off-Modern Landscapes. \\ By György Kalmár. Cham: Palgrave Macmillan, 2020. 273 pp.
}

\section{Orsolya Milián}

Department of Visual Culture and Literary Theory, Faculty of Humanities and Social Sciences, University of Szeged, Egyetem Street 2, 6722 Szeged, Hungary; milianro@yahoo.com

In 2000 the Cannes Film Festival commissioned French cinema's enfant terrible Jean-Luc Godard to create an opening-night short film to celebrate both the century to come and cinema as it sets foot in it. Calling for reflection instead of celebration, Godard completed a sixteen-minute collage or essay film, a kind of afterthought to his eight-part video project Histoire(s) du Cinéma (Histories of Cinema, 1988-1998). In this 2000 short film entitled De l'origine du XXIe siècle (On the Origin of the 21st Century), Godard-juxtaposing documentary and newsreel footage with excerpts from narrative feature films-presented a retrospective view of the twentieth century, mixing scenes of political unrest and war with scenes of private delight and happiness. Thus, for Godard, the origin of the twenty-first century is the history of the twentieth century, though-since he works backwards in time, going from 1990 to 1900, in fifteen-year increments-history is not perceived as progress toward a better future or any goal to be realized, but rather as a series of catastrophes and their aftermaths. In this regard, the constellation and juxtaposition of disparate sound and image fragments that recollect intricately layered twentieth-century (film) historical events is not just a sophisticated experimental cinematic exercise, but an integral element of Godard's conception of history as an endless spiral of repetition and permutation, of dread and despair interspersed with brief moments of hope.

In the bucolic opening sequence, originating from Godard's Hélas pour moi (Oh, Woe Is Me, 1993), and rich in aurous tones (here, in one of his usual superimposed titles, Godard picks out "lor" [gold] from "lorigine", which implies that monetary materialism is inherently interwoven into the twentieth century, and consequently, the twenty-first century), we see a young man playing the violin on a country road, and we hear an operatic aria in the soundtrack. Another man in a 
military uniform walks by the musician, tossing a coin into his fiddle-case, then a young woman appears on a bicycle, who, as passing the man dressed in uniform, says to him in an off-hand manner: "Good-bye, Ludovic, are you off to war?" The opening scene constitutes a concise introduction to what follows: in the same way as pastoral peace is disrupted by a matter-of-fact mention of war, so blends the subsequent audio-visual montage images of joy with images of death. Thus, the next shot superimposes a woman fondling her genitals-an obvious allusion to Gustave Courbet's painting Lorigine du monde (The Origin of the World, 1866) - on a sunset on water, then the westering sun dissolves into a close-up of a sexual intercourse, ending abruptly with the click of a camera shutter, perhaps suggesting the death of taking pictures, the death of filmmaking itself. Afterwards, the music suddenly stops, we hear a woman's shriek, and, while we are reading the last words of the film title ("du XXIe siècle"), we hear bombs exploding. Then Godard cuts to a bus filled with soldiers and refugees of the 1990s Yugoslav Wars, as they slowly proceed during night-time from the left side of the frame to the right in complete silence, followed by the screen fading to black accompanied with the sound of machine gun fire and the reiteration of the woman's shriek.

Without going into further detail, Godard's powerful masterpiece of complex visual and aural montage constantly quotes haunting images of war and genocide, or rape and humiliation, blending and contrasting them with images of women smiling, couples courting, marrying, and making love or people dancing, and, though images of violence are in distinct majority, these persistently recurring moments of joy and happiness act as a resisting and opposing force to the disastrous historical events catalogued in the short film. On the one hand, the abundance of images of war and dead bodies eradicates somewhat the differential specificity of the twentieth century historical events commemorated, leaving the viewer with the sense that we humanity have lived through a series of crises. One could even argue that we, or many of us, have lived and continue to live in a perpetual crisis with interspersed transient periods of joy and happiness that we can achieve mostly in the private sphere-in spite of history. On the other hand, since the European continent is the protagonist in the short film's geopolitical vision, De l'origine du XXIe siècle showcases Godard's view of Europe as an entity made up of national histories and cultures whose violent and political conflicts in the past are at the risk of being forgotten. In this sense, his short film is not only a warning of what might come after the twentieth century, but can also be interpreted as a form of resistance against the homogenization of cultural diversity by a global, imperialistic capitalism.

Being sceptical of any celebratory tone, Godard's reverse historiography in De lorigine $d u$ XXIe siècle faithfully captured the mood of anxiety surrounding the turn of the new millennium and left little space for optimism. Two decades have 
passed since the making of this short essay film, and today it seems that even the remaining optimism has waned and has given way to widespread dissatisfaction and loss of faith in progress-or the Rifkinian European Dream-among Europeans. Apparently, Godard was right to be prudent, since the twenty-first century has only exacerbated crises rooted in the previous one (such as economic neoliberalism, rising inequality, declining upward mobility, societal atomization, forced migration, the weakening of the welfare state, the technological commodification of human life, the destruction of ecosystems, global warming, etc.) or has brought new crises to our lives (for example the Iraq War of 2003-2011 and its consequences, the rise of left and right-wing populism, and the global coronavirus pandemic). In parallel to these developments, turn-of-the-century European arthouse cinema has continuously reflected on the socio-political and economic tribulations of our continent: many European filmmakers, including the Dardenne brothers, Ken Loach, Aki Kaurismäki, Kornél Mundruczó, Costa-Gavras and others have addressed current socio-political and economic issues, creating so-called socially engaged films.

It is no wonder then that crisis in its multifaceted form has recently been a popular topic within film studies dealing with contemporary European cinema. To mention a few recent books that concentrate on contemporary crises as represented in European cinema or the crisis of cinema itself, one might name two remarkable collective volumes, ${ }^{1}$ and naturally, the proper topic of this review, György Kalmár's monograph. These three volumes offer a wide range of perspectives on the ways in which twenty-first century-or, in the case of Cinema of Crisis. Film and Contemporary Europe, post-1989-European cinema has engaged with numerous national and global crises, also laying out aesthetic and ideological analyses. All three books pay special attention to the 2008 financial crisis and the social frustrations that grew out of the economic disempowerment due to austerity measures or deregulated marketization. They each recognize that the 2008 crisis was only one event in a much longer and larger process of neoliberalization that impacted the different regions of Europe in divergent ways. However, out of the three, only the collective volume edited by Thomas Austin and Angelos Koutsourakis comprises a more minutely detailed larger time frame, tracing the problems back to the eighties and the nineties, the period of increased financialization, de-industrialization and outsourcing of production in the West, and dramatic privatization and deregulation of labour markets in Eastern Europe after 1989. Although these processes and their after-effects have played out differently in each country, the European films examined and their analyses in these books-covering a wide geographical and generic range-attest to a systemic crisis of neoliberal capitalism that has not only

1 Kaklamanidou and Corbalán, eds, Contemporary European Cinema; Austin and Koutsourakis, eds, Cinema of Crisis. 
caused shrinking opportunities and precariousness for millions of people (except, of course, the wealthiest one percent), but has produced disenfranchised communities everywhere due to its ideology of hyper-individualism and careless consumerism, coupled with its utopia of endless growth and steady progress for everyone in our global village.

In this era of the "Capitalocene"- to use Jason W. Moore's term-characterized by escalating discontent and disillusionment, it is hardly surprising that an explicit or implicit critique of neoliberalism runs through all the chapters in Post-Crisis European Cinema. White Men in Off-Modern Landscapes, though the author does not treat neoliberal economization as the root cause of the socio-political issues he examines in his book. György Kalmár, as many other scholars before him, convincingly detects that in the twenty-first century we live in a time of reconfiguration of paradigms and traditional approaches, that nowadays we are experiencing an epistemological break (which Robin van den Akker and Timotheus Vermeulen denominate as "metamodernism"). With regard to periodization, Kalmár holds back from announcing the end of modernity, and implicitly assumes that postmodernism is at an end. The author criticizes Francis Fukuyama's concept of the end of history, declaring that history has not come to a halt at all, a statement which seems to be a commonplace in recent political philosophy. In order to designate our era, he leans on Svetlana Boym's notion of the "off-modern", a way of reconsidering unexplored avenues of modernity where "tradition, reflection and longing, estrangement and affection go together". ${ }^{2}$ As Kalmár points out, the project of the Enlightenment or modernity with its belief in everlasting progress has been derailed, and in our days ever more social groups are rediscovering and regressively returning to the "ghosts of the past" (p. 7), such as religious fundamentalism, radical nationalism, overt racism, and hegemonic masculinity.

In the author's view, "post-crisis" does not denominate the end of a crisis, but the period in which the effects of a crisis unfold. He highlights 9/11 and the 2008 financial crisis as two significant turning points that have shaped our twenty-first century condition. The "crisis" in the book's title, in effect, has an impressively wide range of meanings, spanning from the intellectual and the societal to the economic and the political, as the author seeks to map today's cultural and ideological developments by way of European films produced in the twenty-first century. Kalmár's project with Post-Crisis European Cinema. White Men in Off-Modern Landscapes is two-fold: first to provide and examine cinematic examples of the current socio-political transformations, contextualizing them in a larger socio-cultural and ideological framework, and second to use contemporary European cinema as a diagnostic and critical tool to explore both our changed socio-political situation and the new 
cultural logic of the twenty-first century. He carries out interdisciplinary research, approaching the selected films from the perspectives of masculinity studies, sociology, philosophy, and film studies. To portray the current situation, Kalmár focuses on twenty-first century narrative feature films created by male directors mostly working in the art movie or auteurist tradition. However, some cinematic narratives analysed in the book-for instance Billy Elliot (Stephen Daldry, 2000), This Is England (Shane Meadows, 2006), or the films scrutinized in the chapter Unprocessed Pasts-do not deal with the 2000s but with events in the 1980s or even earlier. Accordingly, in terms of outlining the twenty-first century cultural logic or, to invoke Raymond Williams's terminology, its "structure of feeling", there is some inconsistency in the book.

The author narrows down his investigation to the European cinematic representation of less or underprivileged white heterosexual men, since in his perception "the recent changes in (typically less privileged) white male communities lie at the heart of the new century's most dramatic ideological and political changes" (p. 1). In this regard, this book is an organic continuation of Kalmár's previous monograph, ${ }^{3}$ in which he analysed the representation of male identities in post-1989 Hungarian cinema. Seeking to explore the dominant characteristics of twenty-first century socio-cultural shifts and the new forms of male identity, in each chapter the author brings together three films around a symptomatic topic, though-except for drug addiction and right-wing political extremism-most of them are not specifically or exceedingly male-related problems, while other male-specific issues (such as fatherhood) or overwhelmingly male activities (such as domestic violence or delinquent behaviour) are either only tangentially mentioned or completely ignored. Kalmár's book undoubtedly makes an important contribution to the understanding of twenty-first century white masculinities and the newly emerging types of male identity, but in regard to delineating contemporary European concerns or the cultural logic of the new century, a more inclusive analysis of socio-economic experiences would have been necessary so as to produce a more nuanced and accurate description of the Europe we live in.

After an introductory chapter, which outlines the book's conceptual framework, using the notions of time, crisis, white masculinity, and European arthouse cinema, Kalmár carefully arranges his film readings into six thematic chapters, organized along the concepts of retreat, the unprocessed past, addiction and escapism, migration, the shift to the far right and white supremacism, and ageing. Each chapter is introduced with a theoretical and historical sketch of the socio-cultural or political context of the respective socio-political symptom. The case studies assembled in the chapters include films from diverse regions of Europe, ranging from Bulgaria, Hungary, Romania and Poland to Germany, Greece, France, Italy, Sweden, 
and the United Kingdom. Although all the selected films are firmly rooted in their respective national or regional (socio-cultural, historical, political, economic, and mediatic) contexts-explored in the book to varying degrees of detail -, they all deal with wider European or global concerns.

The first one of these consists in a shift in the socio-cultural and geopolitical space occupied by white European men. By examining The World is Big and Salvation Lurks Around the Corner (Stephan Komandarev, 2008), Delta (Kornél Mundruczó, 2008) and Suntan (Argyris Papadimitropoulos, 2016), the chapter Rites of Retreat and the Resignification of European Cultural Geography identifies a new shift in European filmic journeys in that the paths of the male protagonists of these movies lead back from Western Europe to Eastern European homes, from urban areas to the country, from the public to the private sphere. Kalmár introduces the concept of the "retreat film" as a sub-category of return films in order to designate the symbolic journeys taken by the protagonists. He contends that their spatial movements can be interpreted as ritualistic retreats usually triggered by frustration or disappointment, during which a regressive process evolves that manifests not only in the protagonists' return travel, but also in their selfhood and personality. These men, who may feel a loss of their social status, retreat to their place of origin or local roots and traditions, stepping back from the public sphere, but-despite our assumptions-ultimately they will not find their place in their presumed homes, and will not achieve full membership in society.

The next chapter, Unprocessed Pasts, concentrates on twenty-first century changes in the European memory landscape. Focusing on problematic historical heritages as depicted in Amen (Costa-Gavras, 2002), Days of Glory (Rachid Bouchareb, 2006) and Cold War (Pawel Pawlikowski, 2018), Kalmár investigates memory strategies built around historical traumas that in his view define both the "official identity politics" (p. 29) of the European Union and contemporary European culture. He points out that the foundational narrative of the European Union, created by the core countries, embraces a narrative of guilt regarding Second World War atrocities (so as to never repeat history), and that a self-critical and ethical, victim-oriented approach to history has become institutionalized in Western Europe. He warns of the dangers of dogmatism, conformism and moral grandstanding. He does not deny the fact that collective remembering and our "sentiments of guilt, shame and regret" (p. 74) regarding "the origin of the twenty-first century" - to quote Godard-are essential for never repeating past horrors, but, while not elaborating on the knowledge deficit in Eastern Europe about our twentieth century histories, he notes that the Western European memory politics of regret and guilt, emerging as a dominant trend since the 1990s, has been counterproductive. He argues that Amen and Days of Glory were born under the aegis 
of the most canonical European cultural technique of remembering, namely the "paradigm of 'politics of regret' and 'ethical remembering"' (p. 104), while Cold War discloses a different model of collective memory. Unlike in the other two films, the central theme in Cold War is not history or politics but passionate love, and at first sight, it might seem that the historical context-the East-West divide during the Cold War-is touched upon only on the surface and treated just as an obstacle between the two lovers. However, in his profound analysis, Kalmár demonstrates that there is a "metaphorical cross-referencing" between the plot and the historical narrative, the romantic pair, and their spatial and temporal environment, and thus, Pawlikowski's film elucidates cultural differences between Eastern and Western Europe and becomes a historical allegory of the East-West relationship, characterized by a 'neither with nor without you' ambivalence.

The fourth chapter focuses on films about addiction and other escapist behaviours. Sociological studies have shown that compared with women, men are typically more exposed to alcoholism and drug addiction (though the opioid overdose crisis is increasingly affecting young white females in the United States). Kalmár emphasizes that, in his perception, addiction is not a consequence of individual psychopathology, gene map or moral weakness, but a symptom of distressing levels of anxiety and misery experienced both individually and socially. The men in the films examined here are in a state of crisis (escalated by the demands of society to succeed in all areas of life), as they struggle to find their way in society or are forced to face their past traumas and mistakes. By discussing three films with dissimilar conceptualizations of addiction and escapism-Billy Elliot (Stephen Daldry, 2000), T2 Trainspotting (Danny Boyle, 2016) and Kills on Wheels (Attila Till, 2016)-the author points out that while in the case of Billy Elliot individual escape is still possible and professional ambitions can be fulfilled, the other two films are much more sceptical of this cultural myth of self-realization and upward mobility to the point that, in the case of the Hungarian Kills on Wheels, "finding the inner strength to pull oneself up just enough to escape suffocation seems to be a good enough goal that qualifies as a happy ending" (p. 145).

The fifth chapter deals with filmic depictions of international migration, one of the critical issues in contemporary European politics. The state of crisis in Europe due to the mass arrival of migrants and refugees and the continuing debates over their assimilation in European societies are the primary concerns of the cinematic productions analysed here: Terraferma (Emanuele Crialese, 2011), Morgen (Marian Crişan, 2010) and Jupiter's Moon (Kornél Mundruczó, 2017). Kalmár argues that large-scale international migration constitutes a crisis not only for the migrant or refugee, but also for the host country, and for their cinematic representation. Therefore, while exploring the ethical, epistemological, and cinematic pitfalls inherent in filmic representations of 
encounters with otherness, he investigates both a socio-political and an accompanying artistic crisis. Kalmár notes that the films in question are put into a kind of double bind in that their well-meaning directors follow a humanitarian principle, employing the trope of victimhood for migrants and asylum seekers, while trying to steer clear from alarmist sensationalism, domesticating otherness, and creating spectacles of suffering. These films avoid representations that could evoke xenophobia; hence they do not feature young single male migrants or refugees (and when they still do, as in the case of Jupiter's Moon, they tend to attribute angelic qualities to them), which in the author's view serves to diminish European fears concerning sexually violent acts committed by male migrants or refugees. The main characters of these films never commit anything that would seriously offend cultural and moral norms across Europe, and eventually, they represent "idealised European fantasies of otherness" (p. 178). Kalmár persuasively shows that international migration has created new challenges for European filmmakers and has led to a crisis of cinematic representation, in connection with which he concludes that "the fear of showing images that could be appropriated for racist or xenophobic interpretations may compromise the imperative to create complex, authentic, balanced representations" (p. 178).

Chapter six, Lads of the New Right, centers on the revival of the far-right as a significant electoral force and the filmic representations of radicalizing white men. The author reconstructs the factors that contributed to the rise of the new right in the twenty-first century, foregrounding the 2008 financial crisis that has left a large part of the population receptive to appeals to blood and nation as a feasible form of collectivism. By analyzing This is England (Shane Meadows, 2006), The Wave (Dennis Gansel, 2008) and July 22 (Peter Greengrass, 2018), Kalmár outlines their shared characteristics and their different stylistic, ethical, and political approaches to representing the new right and political extremism. He finds that all three films put radicalized men at the centre of visual fascination, but they differ in how they relate to this visual interest in far-right political extremism and violence. In the case of This Is England and The Wave, where most of the characters do not commit extreme violent acts, transgressive attitudes and deeds are portrayed cinematically in a humanizing, almost compassionate manner, and the youngsters' political radicalism is depicted as a psychological reaction triggered by social marginalization and lack of familial nurturing. In contrast, the filmmakers of July 22 have an ethical and social responsibility to show empathy for the families whose lives were upended by Anders Breivik, a Norwegian right-wing extremist, who killed seventy-seven people (mostly teenagers) in a bombing and shooting rampage in Oslo and on Utøya Island on 22 July 2011, therefore the monstrous figure of the mass murderer is represented with a strategy of dehumanization and lack of empathy that alienates spectators from identifying with the perspective of the perpetrator. 
The last analytical chapter turns to another rampant crisis of the twenty-first century: it explores the problems of ageing societies through the figures of angry old men in Tyrannosaur (Paddy Considine, 2011), I, Daniel Blake (Ken Loach, 2016) and A Man Called Ove (Hannes Holm, 2015). Kalmár delineates the traditional ways of filmic representations of elderly men and distinguishes a shift in their twenty-first century cinematic depictions. By showing old white men with reduced social status and frustrated by fast technological and social changes or malfunctioning institutions, the films criticize both the demise of the welfare state and the breakup of old-style communities built around mutual support and care for each other. In this sense, all the vulnerable protagonists of these films can be interpreted as allegorical depictions of a crisis resulting from the disappearance of an old lifeworld, sense of collectivity, and ethos.

Instead of meticulously tying together the many threads discussed thus far, the final Conclusions mark out some general trends in twenty-first century European arthouse or middlebrow cinema and corroborate the author's findings by comparing his results with those published in two notable volumes of film studies. ${ }^{4}$ Kalmár points out that European cinema is sensitive to contemporary socio-political or economic problems, but its twenty-first century shifts in story-telling or modes of representation are less radical or dramatic than, for example, those of politics. Acknowledging the fact that European cinema continues to take its social responsibility seriously, the author states that among the films analysed in his book the most original ones tend to tackle issues that do not ignite vivid political debates or so-called 'culture wars' (for instance, addiction or ageing), while films dealing with hyper-politicized topics (for instance, international migration) tend to make compromises regarding complex and authentic cinematic representation.

Even though it focuses solely on the cinematic representations of the social group of less or underprivileged white men, Post-Crisis European Cinema. White Men in Off-Modern Landscapes succeeds in outlining crucial issues in the current European climate. Although the book analyses a relatively small corpus of films, and, in the end, fails to comprehensively describe the new cultural logic of the twenty-first century, it offers compelling and thought-provoking readings on cinematic responses to contemporary crises and their socio-political, cultural, and historical contexts. The depth of each film analysis will undoubtedly enrich readers' understanding of twenty-first century European film culture and contemporary white masculinities. Accordingly, this monograph is a welcome addition to an already significant corpus of books that provide fascinating or provocative (film) historical records of a Europe which seems to be in a state of crisis. 


\section{Bibliography}

Austin, Thomas and Angelos Koutsourakis, eds. Cinema of Crisis. Film and Contemporary Europe. Edinburgh: Edinburgh University Press, 2020.

Boym, Svetlana. The Future of Nostalgia. New York: Basic Books, 2001.

Elsaesser, Thomas. European Cinema and Contemporary Philosophy. Film as Thought Experiment. London: Bloomsbury Publishing, 2019.

Kaklamanidou, Betty and Ana M. Corbalán, eds. Contemporary European Cinema. Crisis Narratives and Narratives in Crisis. London: Routledge, 2018.

Kalmár, György. Formations of Masculinity in Post-Communist Hungarian Cinema. Labyrinthian Men. Cham: Palgrave Macmillan, 2017. doi.org/10.1007/9783-319-63664-1

Petrie, Duncan, ed. Screening Europe. Image and Identity in Contemporary European Cinema. London: British Film Institute, 1992. 